\title{
As relações inter-raciais
}

\section{The inter-racial relations}

\section{Les relations inter-raciales}

\author{
Renata Paschoalotto da SILVA
}

\section{RESUMO}

Acompanhei a professora Maria José durante dois dias em uma sala da sexta série com o objetivo de analisar como ocorre a questão das relações inter-raciais. No segundo dia do meu trabalho, introduzi atividade que havia preparado a partir dos encontros realizados em "espaço de criação".

Palavras-chave: Transposição Didática, Relações Inter-Raciais, Preconceito, Negro, Discriminação, Sociedade.

\section{ABSTRACT}

I accompanied teacher Maria José during two days in a classroom of the sixth year with the objective to analyze as the question of the inter-racial relations takes place in her class. In the second day of my work, I applied a pedagogical activity that I had prepared, based in the subjects studied in "space of creation".

Index terms: Didactical Transposition, Inter-Racial Relations, Preconception, Black People, Discrimination, Society.

\section{RÉSUMÉ}

J'ai accompagné l'enseignante Maria José pendant deux jours dans une salle de quatrième avec l'objectif d'analyser comment se produisent les relations inter-raciales. Le second jour, j'ai introduit une leçon préparée avec les connaissances acquises lors de mon apprentissage à'l'espace de création".

Mots-clés: Transposition Didactique, Relations Inter-Raciales, Préjugé, Noir, Discrimination, Société. 
No primeiro dia de trabalho de observação em escola pública da cidade de São Paulo, eu tive a oportunidade de observar toda a escola, inclusive durante o intervalo dos alunos, e fiquei com a impressão de que a escola se enquadra no estereótipo da escola pública: muitos estragos, carteiras velhas, paredes sujas, banheiros mal cheirosos. Os funcionários são desanimados, grosseiros com os alunos, e comigo também o foram, até que, finalmente, consegui ser atendida pelo coordenador pedagógico da instituição.

Entretanto, não tive a mesma impressão em relação aos professores, principalmente da professora que acompanhei durante trabalho de intervenção pedagógica que se mostrou muito interessada pelo assunto que eu trazia. Aparentemente, os alunos demonstraram gostar bastante dela e tinham até liberdade para fazer algumas brincadeiras com a mesma e, em nenhum momento, ouvi comentários ou falas preconceituosas da mesma acerca da sua turma.

Os alunos também se relacionavam muito bem entre si, não havia divisão na sala entre negros e brancos e todos estavam juntos nas conversas, exceto os alunos mais tímidos. As meninas, naquele dia, estavam inquietas por conta de um menino da oitava série que muito as interessava, ele era popular devido à desenvoltura e aparência: um garoto alto, mulato e fazia o estilo hip-hop.

No dia seguinte, a professora já sabia que eu iria fazer a intervenção didática e estava de acordo. Comecei falando sobre o início da escravidão: como os negros eram transportados nos navios, em que iriam trabalhar aqui no Brasil e como foram tratados pelos coronéis, açoitados, morando em senzalas e recebendo má alimentação. 
Falei também que muitos dos negros fugiam e se refugiavam em quilombos, enquanto outros conseguiam suas cartas de alforria, mas que, mesmo depois do fim da escravidão, os negros continuaram a ser desrespeitados e tinham sua dignidade ferida.

Nesse ponto, comentei que, atualmente, muitos afro-descendentes continuam em situação de marginalização, são discriminados e recebem os piores salários na sociedade brasileira. São alvos de suspeita em blitz policiais devido à cor de sua pele estar associada à criminalidade.

Começamos a conversar um pouco sobre quem da sala já havia sofrido alguma forma de discriminação e um garoto disse que estava em um supermercado com seus primos e percebeu que sempre havia algum segurança perto deles, ele achava que era pelo fato de serem negros, pois não estavam "zuando" [sic] no supermercado.

Uma das meninas relatou que estava em casa quando uma pessoa bateu no portão. Quando foi ver quem era, a mulher pediu para que chamasse sua patroa, ela disse que ela era a patroa.

Esses foram os relatos "mais fortes" que ouvi. As outras manifestações dos alunos foram comentários pequenos e com pouca argumentação como: "ninguém gosta de preto" [sic] e "eu não gosto de preto mesmo" [sic].

Acredito que esses dois últimos comentários foram em tom de brincadeira, pois os meninos eram amigos, e a classe, como eu havia dito antes, se relaciona muito bem. Alguns alunos não demonstraram nenhum tipo de interesse pelo o que eu estava falando: uma menina fazia a sobrancelha e alguns ouviam música. 
Ficou claro para mim que eles percebem e sofrem com o preconceito na sociedade. A maioria dos alunos não conhecia a história da escravidão, mesmo assim, eles sabiam que o preconceito está incutido na nossa sociedade.

\section{Autora:}

\section{Renata Paschoalotto da Silva}

Ex- aluna do ensino básico da Escola Estadual Fernão Dias Paes. Estudante do terceiro ano do curso de Pedagogia da Universidade de São Paulo. Concluí o primeiro e o segundo grau na Escola Estadual "Fernão Dias Paes" (2002). Atualmente, sou aluna de Espanhol a distância pelo Instituto Cervantes. Ex-estagiária do "Projeto Ler e Escrever" (2006).

Contato: renata.paschoalotto.silva@usp.br

\section{Como citar este depoimento:}

SILVA,Renata Paschoalotto da. As relações inter-raciais. Revista ACOALFAplp: Acolhendo a Alfabetização nos Países de Língua portuguesa, São Paulo, ano 3, n. 6, 2009. Disponível em: $<$ http://www.acoalfaplp.net>. Publicado em: março 2009.

Recebido em junho de 2008/ Aprovado em julho de 2008 